\title{
Closing the Phenotypic Gap between Transformed Neuronal Cell Lines in Culture and Untransformed Neurons
}

\author{
Tereance A. Myers ${ }^{1,2}$, Cheryl A. Nickerson ${ }^{3}$, Deepak Kaushal ${ }^{1,4}$, C. Mark Ott $^{5}$, Kerstin Höner \\ zu Bentrup ${ }^{4}$, Rajee Ramamurthy ${ }^{6}$, Mayra Nelman-Gonzalez ${ }^{7}$, Duane L. Pierson ${ }^{5}$, and Mario \\ T. Philipp ${ }^{1,4}$ \\ 1 Division of Bacteriology \& Parasitology, Tulane National Primate Research Center, 18703 Three Rivers \\ Rd Covington, LA 70433, USA
}

2 Program in Molecular \& Cellular Biology, School of Medicine, Tulane University Health Sciences Center, 1430 Tulane Ave. New Orleans, LA 70112, USA

3 Center for Infectious Diseases \& Vaccinology, The Biodesign Institute, Arizona State University P.O. Box 875401 Tempe, AZ 85287, USA

4 Department of Microbiology \& Immunology, School of Medicine, TUHSC, 1430 Tulane Ave. New Orleans, LA 70112, USA

5 NASA-Johnson Space Center, Houston, TX 77058, USA

6 Department of Biological Sciences, Florida International University, University Park Campus, Miami, FL 33199

7 Wyle Laboratories, NASA-Johnson Space Center, Houston, TX 77058, USA

\begin{abstract}
Studies of neuronal dysfunction in the central nervous system (CNS) are frequently limited by the failure of primary neurons to propagate in vitro. Neuronal cell lines can be substituted for primary cells but they often misrepresent normal conditions. We hypothesized that a 3-dimensional (3-D) cell culture system would drive the phenotype of transformed neurons closer to that of untransformed cells, as has been demonstrated in non-neuronal cell lines. In our studies comparing 3-D versus 2dimensional (2-D) culture, neuronal SH-SY5Y (SY) cells underwent distinct morphological changes combined with a significant drop in their rate of cell division. Expression of the proto-oncogene Nmyc and the RNA binding protein HuD was decreased in 3-D culture as compared to standard 2-D conditions. We observed a decline in the anti-apoptotic protein Bcl-2 in 3-D culture, coupled with increased expression of the pro-apoptotic proteins Bax and Bak. Moreover, thapsigargin (TG)induced apoptosis was enhanced in the 3-D cells. Microarray analysis demonstrated significantly differing mRNA levels for over 700 genes in the cells of the two culture types, and indicated that alterations in the G1/S cell-cycle progression contributed to the diminished doubling rate in the 3D-cultured SY cells. These results demonstrate that a 3-D culture approach narrows the phenotypic gap between neuronal cell lines and primary neurons. The resulting cells may readily be used for in vitro research of neuronal pathogenesis.
\end{abstract}

Correspondence: Mario T. Philipp, Division of Bacteriology and Parasitology, Tulane National Primate Research Center, Tulane University Health Sciences Center, 18703 Three Rivers Road, Covington, LA 70433, USA. Tel: 985871 6221; fax: 985871 6390; email: philipp@tulane.edu.

Publisher's Disclaimer: This is a PDF file of an unedited manuscript that has been accepted for publication. As a service to our customers we are providing this early version of the manuscript. The manuscript will undergo copyediting, typesetting, and review of the resulting proof before it is published in its final citable form. Please note that during the production process errors may be discovered which could affect the content, and all legal disclaimers that apply to the journal pertain. 


\section{Keywords}

neuroblastoma; 3-D cell culture; differentiation; phenotype

\section{INTRODUCTION}

In vitro studies of disease pathogenesis in the CNS are often conducted with cultures of primary cells, but when the cells in question are neurons, in particular, human neurons, this becomes problematic. Because most post-embryonic neurons do not divide, their usefulness in primary culture is limited (Encinas et al., 2000; Smith, 1996). Transformed neuronal cell lines of both human and animal origin have thus become a requisite tool in studies of neuronal dysfunction in the CNS.

Although transformed neurons in cell lines will divide, they are known to exhibit an arrested state of cellular differentiation (Abbott, 2003; Guidi et al., 2002; Hanada et al., 1993; van Golen et al., 2003; Zhang, 2004). Expression of the proto-oncogene N-myc is typically elevated and resistance to apoptosis is increased, making the interpretation of experimental results with these cells difficult when compared to untransformed cells (Fan et al., 2001; Kang et al., 2006; Smith et al., 2004; van Golen et al., 2003; van Noesel et al., 2003).

In addition to the limitations introduced by transformed cell lines, traditional monolayer or 2D culture systems are often themselves inadequate to realistically model in vivo conditions (Lelkes et al., 1998; Nickerson et al., 2001; O'Brien et al., 2002; Zhang, 2004). Gravity induced sedimentation, non-homologous delivery of nutrients and a lack of cell-cell and cell-extra cellular matrix contacts are all potential limitations of 2-D cell culture (Abbott, 2003; Guidi et al., 2002; LaMarca et al., 2005; Nickerson et al., 2001). Perhaps more importantly, 2-D cell culture approaches are known to alter gene expression, to hinder cellular differentiation and to prevent formation of the complex 3-D cellular architecture commonly found in an intact tissue (Abbott, 2003; Eisenstein, 2006; Freshney, 2000; Honer zu Bentrup et al., 2006; Nickerson et al., 2001; Schmeichel and Bissell, 2003; Zhang, 2004). While matrigel, collagen, peptide and synthetic nanofiber scaffolds are each being used and developed as more realistic procedures for in vitro cell culture (Abbott, 2003; O'Brien et al., 2002; Schmeichel and Bissell, 2003; Zhang, 2004), NASA-engineered rotating wall vessels (RWV) are also being employed to establish a fluid suspension culture that is capable of inducing biologically meaningful 3-D growth in vitro (Gao et al., 1997; Guidi et al., 2002; LaMarca et al., 2005; Nickerson and Ott, 2004). During culture in a RWV, individual cells aggregate into 3-D tissue-like assemblies developing enhanced states of differentiation and cross communication through cell-cell contacts. Gas exchange and nutrient delivery are optimized under these conditions, (Guidi et al., 2002; Nickerson et al., 2001) and the cellular phenotypes, as compared to their 2-D cultured counterparts, become functionally and morphologically more similar to the parental tissues and organs that they represent (Hammond and Hammond, 2001; Lelkes et al., 1998; Nickerson and Ott, 2004; Nickerson et al., 2007; Unsworth and Lelkes, 1998; Zhang, 2004).

Our lab is interested in studying the pathogenesis of Lyme neuroborreliosis. The inherent limitations of primary neuronal culture in vitro prompted us to incorporate transformed neurons into our research design. As molecular and cellular changes that accompany the conversion of normal cells into states of disease or malignancy are altered by 2-D growth (Gao et al., 1997; Guidi et al., 2002; Kunz-Schughart et al., 1996), we wanted to establish a 3-D model of in vitro neuronal culture, to assess whether this procedure would attenuate the phenotypic differences that exist between transformed and untransformed neurons. By culturing SY cells under the gentle, low-shear conditions in a RWV, we have succeeded in obtaining a cell line that expresses classic morphological and functional patterns of neuronal differentiation. 
The SY cell line is an adrenergic " $n$ " type clone of the "mixed cell" human neuroblastoma line SK-N-SH and has been used extensively in standard 2-D cultures to study neuronal function, growth, damage in response to insult, degeneration and differentiation (Biedler et al., 1973; Garcia-Gil et al., 2003; Hanada et al., 1993; Ho et al., 2005; Martinez and Pascual, 2007; Ribas and Boix, 2004). By culturing SY cells under the gentle, low-shear conditions in a RWV, we have succeeded in obtaining a cell line that expresses classic morphological and functional patterns of neuronal differentiation.

\section{MATERIALS AND METHODS}

\section{Cell Culture and Reagents}

2-D System-Human SY neuroblastoma cells (American Type Tissue Culture Collection ATCC CRL-2266) and PC12 rat pheochromocytoma cells (ATCC CRL-1721) were each seeded into separate T75 flasks with medium renewal every 3-7 d. The culture flasks for PC12 cells were coated with PureCol collagen (Inamed). Cell propagation was performed as per the ATCC product sheet. Nerve growth factor (Sigma) was added to the PC12 medium at $50 \mathrm{ng} /$ 2-D. Penicillin (100 units/ml), streptomycin (100 units $/ \mathrm{ml})$ and amphotericin B $(0.25 \mu \mathrm{g} / \mathrm{ml})$ (Gibco/Invitrogen) were added to all media. Trypsin $(2.5 \%) / \mathrm{EDTA}(0.38 \mathrm{~g} / \mathrm{L})$ was used to dislodge the cells, and trypan blue ${ }^{\mathrm{TM}}$ stain was used to assess cell viability (Gibco/Invitrogen). Samples from the 2-D cultures were harvested at a passage $\leq 20$.

3-D System-Approximately $10^{7}$ viable 2-D-cultured SY or PC12 cells were dislodged by trypsin and loaded into 50-ml RWVs (Synthecon) containing $200 \mathrm{mg}$ of Cytodex-3 $3^{\mathrm{TM}}$ microcarrier beads (Amersham Biosciences) suspended in complete growth medium (ATCC product sheet). Entirely filled vessels were then attached to a rotator base (Synthecon) with initial speed typically set at 18-22 RPM. The RPM were adjusted during cultivation to maintain the cell aggregates in suspension. Complete removal of all bubbles was addressed upon initial rotation and daily thereafter. Cell viability assays and medium replacement were performed every $2-$ $5 \mathrm{~d}$. The cells were collected after $2-4 \mathrm{wk}$ (see individual results) of culture. Although minimal changes were noted at $2 \mathrm{wk}$, we typically found significant molecular marker differences at 3 wk, with small additional changes at 4 wk. For efficiency, 3 wk was used as our standard.

\section{Cell Counting and Proliferation Assays}

3-D cultures were removed from the RWV, dislodged from the Cytodex beads by treatment with trypsin/EDTA, and then dissociated from the beads with $40-\mu \mathrm{m}$ cell strainers (Becton, Dickinson and Company). One million $\left(10^{6}\right)$ 2-D and 3-D cultured SY cells were independently seeded into $10 \mathrm{ml}$ of complete growth medium in T75 culture dishes and allowed to propagate for $5 \mathrm{~d}$. Cells were them removed from the dish, (trypsin/EDTA), and counted in a BrightLine Hemocytometer.

\section{Morphology: Light and Electron Microscopy}

Live cell photographs were imaged with a Sony Cyber Shot digital still camera (DSCF717) attached to a Nikon TMS light microscope. Scanning electron microscopy (SEM) was used to examine changes in the morphology of SY cells as described previously with minor modifications (Nickerson et al., 2001). 2-D cells and 3-D cell aggregates were fixed in 3\% glutaraldehyde, $0.5 \%$ paraformaldehyde in PBS, $\mathrm{pH} 7.2$, for a minimum of $24 \mathrm{~h}$. The samples were flushed in triplicate with filter-sterilized deionized water to remove salts and then transferred for observation to a Philips XL 30 ESEM (FEI Co.). Chamber pressure was adjusted between 1 and 2 torr to optimize image quality. 


\section{Confocal Microscopy}

2-D and 3-D cells removed from culture were washed once in PBS and fixed in 2\% paraformaldehyde (PFA) (USB Corporation) for 5-10 min, permeabilized in PBS with fish skin gelatin (Sigma-Aldrich) and Triton X-100 (ICN Biomedicals) (PBS/FSG/Triton) and blocked in 10\% normal goat serum (Gibco). The fixed 2-D and 3-D cultured cells were equally stained with primary antibodies for $1 \mathrm{~h}$, washed 3 times in PBS and then stained with corresponding secondary antibodies for $45 \mathrm{~min}$. Nuclear stains were combined with the secondary antibodies at a concentration of $0.05 \mu \mathrm{g} / \mathrm{ml}$. Primary antibodies used included antiN-myc, HuD, Bcl-2, Bax and Bak (Santa Cruz Biotechnology). Alexa-488 (green)-conjugated secondary antibodies, and the To-Pro (blue) nuclear stains were from Invitrogen. Propidium Iodide (PI) (red) (Sigma-Aldrich) was used as an alternative nuclear stain. Imaging was performed using a Leica TCS SP2 confocal microscope equipped with three lasers (Leica Microsystems). Six to eighteen $0.2-\mu \mathrm{m}$ optical slices per image were collected at $512 \times 512$ pixel resolution. The pinhole size, gain and contrast, filter settings, and laser output were held constant for each comparison of the 2-D and 3-D image sets.

\section{Western Blot Analysis}

Cells were lysed on ice for 10 min using buffer ( $0.15 \mathrm{M} \mathrm{NaCl}, 5 \mathrm{mM}$ EDTA, $\mathrm{pH}$ 8, $1 \%$ Triton $\mathrm{X}-100,10 \mathrm{mM}$ Tris-HCl, $\mathrm{pH}$ 7.40) supplemented with $5 \mathrm{mM}$ dithiothreitol and a Protease Inhibitor Cocktail for mammalian cells (Sigma-Aldrich). Protein concentrations were measured with the BCA assay (Pierce Biotechnology). After optimization for each sample, total protein ( $40 \mu \mathrm{g} / \mathrm{lane}$ for $\mathrm{N}-\mathrm{myc}, \mathrm{HuD}, \mathrm{Bcl}-2$, and Bak, and $50 \mu \mathrm{g} / \mathrm{lane}$ for Bax) was resolved in $12 \%$ Tris- $\mathrm{HCl}$ pre-cast gels (BioRad), and electrophoretically transferred to nitrocellulose Protran membranes (Schleicher and Schuell BioSciences). Non-specific binding was blocked with 3\% BSA fraction V (Sigma-Aldrich) in PBS-Tween (PBST) at $4^{\circ} \mathrm{C}$ over night. Target proteins were detected with rabbit or mouse primary antibodies for $2 \mathrm{~h}$ at room temperature or at $4{ }^{\circ} \mathrm{C}$ over-night (all antibodies were from Santa Cruz Biotechnology except for $\beta$-actin and $\beta$-tubulin (Abcam). The blots were washed 3 times in PBST and incubated for 45 min with horseradish peroxidase-conjugated anti-rabbit or anti-mouse secondary antibodies (Santa Cruz Biotech.) The blots were again washed 3 times in PBST, developed for 1-2 min in Western Blot Luminol Reagent (Santa Cruz Biotechnology) and visualized using a Kodak Imager 2000 and Kodak Image Analysis Software, or were developed in Immpact DAB from Vector Labs.

\section{Apoptosis assays}

SY cells $\left(1 \times 10^{6}\right)$ cultured in 2-D or 3-D were incubated with or without $10 \mathrm{nM}$ TG. The 2$\mathrm{D}$ and 3-D cells were harvested using trypsin, washed in PBS, and fixed for 5-10 $\mathrm{min}$ in 2\% PFA. Prior to fixation, the 3-D-cultured cells treated inside of the RWV were separated from the beads using a $40-\mu \mathrm{m}$ cell strainer (Becton Dickinson). The fixed cells were permeabilized in PBS/FSG/Triton and blocked with 10\% NGS. Apoptosis was evaluated using the Apoptag TUNEL assay kit (Chemicon). The results were analyzed using a Leica TCS SP2 confocal microscope as described above. Cell morphology consistent with apoptosis including cell shrinkage, nuclear condensation and membrane blebbing were assessed along with the fluorescein staining for TUNEL. The number of apoptotic cells counted was divided by the total (500 minimum) number of cells counted. This protocol was also followed for evaluation of apoptosis in PC12 cells. An increased drug tolerance, 30-nM TG was used in the PC12 assay. 3-D-cultured PC12 samples were stimulated for $5 \mathrm{~d}$ after removal from the RWV to multi-well dishes.

\section{Microarray}

Microarray experiments and analysis of data was performed according to previously described protocols (Kaushal and C.W., 2004; Tekautz et al., 2006). Microarray experiments utilized the 
44,544 70-mer element Human Exonic Evidence based Oligonucleotide (HEEBO) microarray, supplied by the Stanford Functional Genomics Facility

(http://www.microarray.org/sfgf/heebo.doc). RNA was isolated from approximately $5 \times 10^{6}$ 2-D and 3-D cultured cells using an RNeasy kit (Qiagen) plus DNA-free (Ambion), to eliminate DNA contamination. Five micrograms of mRNA was used to incorporate Cy3 (2-D samples) or Cy5 (3-D samples). Labeling, hybridization and scanning utilized previously described protocols (Tekautz et al., 2006). The resulting text data was imported into Spotfire DecisionSite (Spotfire Inc), filtered, and subjected to statistical analysis (Kaushal and Naeve, 2004). Genes whose expression changed by 1.5 fold (with a corrected t-test $\mathrm{P}<0.05$ ) were considered to be differentially expressed in a statistically significant manner. Pathway analysis was performed by uploading significant dataset(s) into Ingenuity Pathways Analysis algorithm. Pathways that were perturbed in a statistically significant manner $(\mathrm{P}<0.05)$ were included in analysis.

\section{QRT-PCR}

RNA was collected as for the microarray analysis. The QuantiFast SYBR Green RT-PCR kit (Qiagen) was used for the QRT-PCR. All assays were performed as per manufacturer's instruction with Qiagen QuantiTect primer pairs in a 96-well block ABI 7700 RT cycler.

\section{Online Supplemental Material}

Details of the microarray data analysis are available on line as supplemental material.

\section{RESULTS}

\section{3-D culture changes the morphology and proliferation rate in SY neuronal cells}

SY cells cultured for $21 \mathrm{~d}$ in the RWV, and then for counting purposes transferred back to 2D culture flasks for $5 \mathrm{~d}$, revealed a decrease in the cell doubling rate from $40 \mathrm{~h}$ to approximately $65 \mathrm{~h}$, with no change in cell viability (Fig. $1 \mathrm{~A}$ ). Because the carrier beads used in our 3-D culture were coated in collagen, we additionally cultured SY cells for 3 and for 4 wk in 2-D flasks coated with collagen. We observed no detectable difference in the morphology, cell viability or doubling rate of 2-D cells cultured on plastic as compared to collagen. Scanning electron microscopy (SEM) revealed important differences in the morphology of SY cells cultured in 2-D or in 3-D. Specifically, only the 3-D-cultured SY cells acquired a parental, tissue-like conformation with dramatic increases in neurite extension, direction and number (Fig. 1 B).

\section{Decreased expression of $\mathrm{N}$-myc and HuD}

Human neuroblastoma cells are typically characterized by de-differentiation. They have reentered S-phase of the cell cycle, and are highly resistant to apoptosis (Kang et al., 2006; van Noesel et al., 2003). Amplified expression of the proto-oncogene N-myc has been correlated with cellular de-differentiation and increased resistance to apoptosis, and is believed to have a crucial role in maintenance of the cells' malignant phenotype (Chagnovich and Cohn, 1996; Grandinetti et al., 2006; Smith et al., 2004; van Golen et al., 2003). The RNA binding protein $\mathrm{HuD}$ functions in stabilizing $\mathrm{N}$-myc mRNA and may consequently enhance steadystate expression levels of this oncogene (Chagnovich and Cohn, 1996; Grandinetti et al., 2006; Lazarova et al., 1999). Reduced expression of the HuD protein could therefore contribute, through destabilization of N-myc, to an increase in cellular differentiation.

Western analysis confirmed a culture-dependent shift in protein expression of these markers (Fig. 2 A). Images obtained with confocal microscopy revealed a diminished level of N-myc and $\mathrm{HuD}$ protein expression in SY cells cultured in 3-D as opposed to 2-D (Fig. 2 B). 


\section{Apoptosis resistance is diminished in 3-D cultured SY and PC12 cells}

Cells over-expressing the anti-apoptotic protein Bcl-2 or cells with depleted pro-apoptotic Bax and Bak exhibit resistance to cell death as induced by mitochondrial dysfunction and ER stress (Elyaman et al., 2002; Henshall et al., 2002; Murakami et al., 2007; Scorrano et al., 2003).

Because increased resistance to apoptosis is one hallmark of a transformed phenotype in many cancer cell lines, we were interested in exploring the effects of 3-D culture on the expression of key proteins in the apoptosis pathway. We found a decreased expression of Bcl-2 coupled with increased Bax and Bak proteins in 3-D cultured SY cells as compared to those cultured in standard 2-D conditions (Fig. 3 A). While confocal imaging clearly indicated increased Bak protein in 3-D cultured cells, Western analysis was not sensitive enough to detect its expression.

Our next consideration was to assess apoptosis functionally and to confirm that our findings were not restricted to a single cell line. PC12 is a rat pheochromocytoma cell line that can be stimulated with nerve growth factor to differentiate into sympathetic-like neurons (Greene and Tischler, 1976). Due to their induced ability to cease division, become electrically excitable and extend neurites, PC12 cells have become an extremely well characterized in vitro model for studies of neuronal differentiation and survival (Attiah et al., 2003; Das et al., 2000; Lelkes et al., 1998; Ulloth et al., 2007; Vyas et al., 2004).

Thapsigargin (TG) is known to induce apoptosis through the passive release of $\mathrm{Ca}^{2+}$ from ER stores. These events lead to subsequent increases in cytosolic $\mathrm{Ca}^{2+}$, stressing both the ER and the mitochondria (Elyaman et al., 2002; Nechushtan et al., 2001; Nguyen et al., 2002; Scorrano et al., 2003; Zong et al., 2003). In order to determine inherent differences in apoptosis between the 3-D and 2-D cultured cells we used the terminal uridine deoxynucleotidyl transferase dUTP nick end labeling (TUNEL) assay. SY cells were incubated with 10-nM TG for 24 hours and for 5 days. The 3-D-cultured SY cells were treated either inside the RWV (3-D(RWV) or after transfer back into standard culture flasks (3-D). We additionally incubated PC12 cells with 30nM TG, for 5-d. All of the 3-D-cultured PC12 cells were treated after transfer back into standard culture flasks. The SY and PC12 cells grown in 2-D culture were treated in their respective dishes.

In a 5-day comparison of TG-stimulated versus non-stimulated control cells, we found an approximate 4 to 7-fold increase in the occurrence of apoptosis in 3-D as opposed to 2-D culture. In a similar 5-d comparison, 3-D cultured PC12 cells were approximately 3-fold more susceptible to apoptosis than were the 2-D cells. At $24 \mathrm{~h}$, a noticeable difference in the degree of apoptosis occurring in stimulated versus control cells was found only in the 3-D(RWV) cells (Fig. 3 B).

\section{SY cells maintain 3-D culture-induced alterations in the phenotypic markers $\mathrm{N}$-myc and $\mathrm{Bcl}-2$ for at least $5 \mathrm{~d}$ after return to 2-D culture}

As many studies of neuronal pathogenesis involve co-cultures of neuronal cell lines with primary glia and/or other live organisms propagated in 2-D culture, we wanted to evaluate the length of time that SY cells would retain a 3-D phenotype once they were transferred back into 2-D culture. We thus examined the expression of N-myc and Bcl-2, two molecular markers closely related to both differentiation and tumorigenicity (Elyaman et al., 2002; Fan et al., 2001; Kang et al., 2006; Pregi et al., 2006; Ribas and Boix, 2004; Smith et al., 2004; van Golen et al., 2003; van Noesel et al., 2003). Assessment of the SY cells that had been "preconditioned" in 3-D culture for approximately $3 \mathrm{wk}$ and were then removed to 2-D culture revealed a 5-d experimental window during which reversion of the culture-induced changes were minimal (Fig. 4). 


\section{Microarray analysis of gene expression in SY cells cultured in 3-D and in 2-D}

In an effort to expand and to further clarify our findings related to the states of differentiation and morphology in 2-D and 3-D-cultivated SY cells, we employed microarray analysis to observe the culture-induced effects on global gene expression. Because abnormalities in the expression and activity of multiple genes often work in concert to effect a transformed cellular phenotype (Hanahan and Weinberg, 2000; Li et al., 2006; Park and Lee, 2003; Tweddle et al., 2001), Ingenuity Pathways Analysis (IPA) software was used to compare the mRNA levels in 44,544 70-mer oligos corresponding to over 24,000 human genes. Cancer, cell morphology and proliferation pathways were among those found to be the most altered (Fig. 5 A). The G1/ $\mathrm{S}$ and G2/M cell cycle check points, as well as the p53 and neuregulin signaling pathways, were also significantly affected (Fig. 5 B).

Along with abnormalities in the p53 tumor suppressor gene pathway, dysregulation of the cell cycle is one of the most frequent alterations found in tumor development, with the inappropriate progression of G1/S being especially common (Kuiper et al., 2007; Park and Lee, 2003; Tweddle et al., 2001; Zhu et al., 1999) In the normal dividing cell, cyclin-dependent kinases (CDKs) form a complex with D/E-type cyclins to phosphorylate the retinoblastoma $(\mathrm{Rb})$ gene, causing the release of bound E2F-family transcription factors. These now unbound E2F proteins then act to drive G1/S phase transition by the activation (or repression) of multiple gene targets affecting cellular growth and proliferation, nucleotide metabolism and DNA synthesis (Ebelt et al., 2005; Jiang et al., 2004; Li et al., 2006; Parisi et al., 2007; Park and Lee, 2003). Histone deacetylases (HDACs) form a complex with bound E2F proteins and are also released upon phosphorylation of Rb. Importantly, HDAC inhibitors have been shown to cause cell cycle arrest in G1 and to function in cellular differentiation and apoptosis (Xiong et al., 1993; Zhou et al., 2000). Because of its strong ties to transformation, we wanted to look more closely at the actual variance reported in the G1/S pathway.

The CDK4/6 inhibitor CDKN2B was found to be significantly up-regulated in 3-D versus 2D cultured SY cells. At the same time, the transcription factor E2F3, HDAC2 and the neuregulin1 (NRG1) gene, whose product promotes growth and proliferation in neuronal cells of the peripheral and central nervous systems (Fallon et al., 2004; Rieff et al., 1999), were each significantly down-regulated (Fig. 5 C). These events clearly indicate arrest in G1. Rb gene expression was also decreased, but without knowing the phosphorylation state of this gene, correlation with the cell cycle is questionable.

\section{RT-PCR confirms the differential expression of G1/S cell-cycle check point genes in 3-D versus 2-D cultured SY cells}

A significant part of our microarray analysis was focused on exploring culture-induced differential gene expression in a neuronal cell line that could indicate phenotypic reversion toward a more normal state. Pathways such as growth and proliferation or the cell cycle checkpoints were of interest. We used RT-PCR to confirm our initial array findings. In order to maintain integrity in this experiment as compared to our microarray analysis, we used aliquots of the same SY 3-D and 2-D cell RNA that was collected for each of the arrays. Expression changes in 3 of the 4 selected genes known to influence the G1/S cell cycle checkpoint matched our microarray data (Fig. 5 D, Table 1).

\section{DISCUSSION}

It is generally accepted that once developing neurons leave the ventricular and sub-ventricular zones of the CNS, they are terminally differentiated and become persistently postmitotic (Herrup et al., 2004; Potter, 2001; Zhu et al., 1999). Although some neurons are generated in the adult brain, neuronal exit from the cell cycle is typically viewed as permanent (Becker and 
Bonni, 2004; Ding et al., 2000; Herrup et al., 2004; Potter, 2001; Zhu et al., 1999). This inability to divide often complicates research requiring primary neuronal cultures. While a handful of human neuronal cell lines are available to researchers, the transformed phenotype of these cells is less than optimal. The SY cell line is an adrenergic " $n$ " type clone of the "mixed cell" human neuroblastoma line SK-N-SH and has been used extensively in standard 2-D cultures to study neuronal function, growth, damage in response to insult, degeneration and differentiation (Biedler et al., 1973; Garcia-Gil et al., 2003; Hanada et al., 1993; Ho et al., 2005; Martinez and Pascual, 2007; Ribas and Boix, 2004). We have applied a transitional cell culture technique to these neuronal cells that attenuates some of the aberrant features characteristic of transformed neurons.

Loss of cellular differentiation combined with an unchecked potential to proliferate has long been a hallmark in the progression of tumorigenesis (Becker and Bonni, 2004; Herrup et al., 2004; Li et al., 2006; Park and Lee, 2003). Differentiation of transformed neurons in 2-D culture can be pursued by the addition of biochemical agents such as phorbol myristate acetate (PMA), retinoic acid (RA), staurosporine (ST) and brain-derived neurotrophic factor (BDNF) (GarciaGil et al., 2003; Lombet et al., 2001). RA and PMA have both been shown to induce the outgrowth of neurites and to diminish cellular proliferation in SY cells, (Hammerling et al., 1987; Wang et al., 2006). Phorbol esters, however, will induce SY cells to differentiate toward a noradrenergic phenotype, while treatment with RA effects a cholinergic phenotype (GarciaGil et al., 2003). Incubation of SY cells with either RA or PMA induces up-regulation of the anti-apoptotic proteins Bcl-2 and Bcl- $\mathrm{x}_{\mathrm{L}}$, whereas differentiation obtained with ST has been shown to notably diminish expression of these proteins (Lombet et al., 2001; Pregi et al., 2006; Ribas and Boix, 2004). This is important because the Bcl-2 family proteins, including pro-apoptotic members such as Bax and Bak and anti-apoptotic proteins such as Bcl-2, figure prominently in molecular pathways of programmed cell death and may play a role in the degree of neuroblastoma cell tumorigenicity (Elyaman et al., 2002; Nechushtan et al., 2001; Scorrano et al., 2003; Zong et al., 2003), and the expression of anti-apoptotic molecules above that of a cancerous state seems incongruous with a less transformed phenotype.

In this report we have shown that the morphology and proliferation characteristics of 3-Dcultivated SY cells align themselves more with a parental untransformed phenotype than those of cells grown in 2-D culture. Two of the classic prognostic markers of tumorigenicity in neuroblastoma, $\mathrm{N}$-myc and $\mathrm{HuD}$ expression, were diminished in 3-D as compared to 2-Dcultured SY cells. A decline in the amount of HuD mRNA and protein in various cell lines has been shown to cause a marked reduction in steady-state levels of mature N-myc mRNA and protein. Interestingly, other researchers have shown that an up-regulation in HuD expression also can positively influence neuronal differentiation. This differentiation occurs via PKCaacute;-mediated neurite outgrowth in mouse embryonic stem cells, in maturing rat neurons, and in PC12 cells, primarily through HuD stabilization of GAP-43 mRNA and tau protein expression (Anderson et al., 2000; Aranda-Abreu et al., 1999; Bolognani and PerroneBizzozero, 2008; Mobarak et al., 2000; Pascale et al., 2005; Pascale et al., 2004). These effects, however, may not be mirrored completely in human neurons and in particular, in transformed SH-SY5Y cells, where differentiation with RA does not produce an increase in either GAP-43 or tau expression (Joshi et al., 2007). Although we found a 3-D culture-induced decrease in Nmyc and HuD protein expression in the SH-SY5Y line, we also observed abundant and extended neuritic processes in the cells. Additionally, there were decreased proliferation rates, and diminished resistance to apoptosis, all changes that are in line with a more normalized neuronal phenotype when compared to the transformed state. HuD is known to stabilize Nmyc, and an amplified expression of $\mathrm{N}$-myc protein is highly implicated in states of neuronal transformation, de-differentiation, and increased proliferation (Lazarova, et al., 1999, Ross, et al., 1997, Grandinetti, et al., 2006, Manohar, et al., 2002, Ball and King, 1997, Chagnovich, et al., 1996, Cohn, et al., 1996, Smith et al., 2004); these phenomena probably involve 
competing and alternative functions effected by $\mathrm{HuD}$ expression, wherein may reside the explanation of the disparities concerning the effect of $\mathrm{HuD}$ expression on differentiation, in other systems.

Numerous reports verify the ability of 3-D growth to sway cellular characteristics toward those of a less transformed state as compared with that of 2-D culture (Abbott, 2003; Carterson et al., 2005; Honer zu Bentrup et al., 2006; Kunz-Schughart et al., 1996; LaMarca et al., 2005; Lelkes et al., 1998; Nickerson et al., 2001; Ribas and Boix, 2004; Straub et al., 2007; Zhang, 2004). In 1997, Bissell et al. showed that breast cancer cells grown in 3-D culture changed their transformed behavior to that of non-cancerous cells, resuming a normalized morphology combined with more typical patterns of growth and proliferation (Abbott, 2003; Schmeichel and Bissell, 2003). Nickerson et al. further demonstrated that 3-D culture can promote cellular differentiation and polarity, some of the key elements perturbed in transformation (Carterson et al., 2005; Honer zu Bentrup et al., 2006; LaMarca et al., 2005; Nickerson et al., 2001; Straub et al., 2007). While researchers have followed different protocols for 3-D culture, e.g. growth on gels and matrices versus fluid culture in a RWV, the trend toward a less transformed phenotype is preserved in numerous cell types. In our model, SY cells became "normalized" in 3-D culture, and were able to maintain a less transformed phenotype for at least $5 \mathrm{~d}$ after return to 2-D growth conditions. Given that 2-D cell cultures are generally easier to handle during experimental procedures than are cells in 3-D culture, this finding adds to the practicality of our model.

Further distancing transformed cells from the normal tissues that they are intended to represent is an increased resistance to apoptosis (Kunz-Schughart et al., 1996; Park and Lee, 2003; Ulloth et al., 2007). We have found 3-D-cultured SY and PC12 cells to be more susceptible to TGinduced apoptosis than the same cells grown in 2-D culture. Because of TG's known association with the intrinsic pathway of ER and mitochondrial induced mortality in which Bcl-2 family proteins are highly implicated, changes in the anti-apoptotic protein Bcl-2 and pro-apoptotic family members Bax and Bak provided a possible mechanism contributing to the enhanced apoptotic response (Elyaman et al., 2002; Scorrano et al., 2003; Zong et al., 2003). The primary hypothesis addressed in this study was that a 3-D culture system would drive the phenotype of transformed neurons closer to that of untransformed cells. We have noted culture-induced changes in the morphology and biomarker expression of our 3-D-cultured SY cells, reflecting a more differentiated, and thus a less transformed, phenotype. We have shown apoptosis resistance to be diminished and have observed a decline in the 3-D-cultured SY cell doubling rate. Microarray analysis comparing 3-D and 2-D-cultured SY cells provided a strong indication that alterations in the G1/S cell cycle progression were contributing to the diminished doubling rate in the 3-D-cultured SY cells. Neuronal cells arrested at this checkpoint are known to either return to G0 and re-differentiate, or die by apoptosis (Becker and Bonni, 2004). Due to the decline in doubling rate and the near-100 percent viability of our 3-D-cultured SY cells, we believe that the cells were returning to quiescence. Confirmation of the array results involved in this pathway was obtained using quantitative real-time (QRT)-PCR. Lending added support to our hypothesis, culture-induced variance in several other prominent pathways leading to transformation and cancer, was also identified on the array.

Microarray analysis has been used by other investigators to screen for the differential expression of SY cell genes propagated in 2-D and 3-D culture conditions ( $\mathrm{Li}$ et al., 2007; Martinez and Pascual, 2007). While focusing on differences in morphology and neurite outgrowth, Li et al., found more than 1700 of 14,564 genes to be differentially regulated in SY cells propagated on collagen matrices. Considering the number of genes being modified, it is reasonable that phenotypic changes beyond those of morphology and neurite extension are occurring. These results, like our own, indicate that continued research in this area will be 
needed to fully characterize the culture-induced changes in gene expression that define 3-D versus 2-D-cultured cells.

The generation of purified primary neurons in numbers satisfactory for experimental study is difficult to achieve with animal cells, and is nearly impossible with human cells. Researchers must therefore rely on transformed cell lines for many studies of pathogenesis in the CNS. These inherent limitations in primary neuronal culture prompted us to establish a 3-D model that could be used in our own research design. The ability to provide a more normalized cellular environment in vitro has improved dramatically in the past few decades, particularly with the use of 3-D culture systems (Abbott, 2003; Guidi et al., 2002; Honer zu Bentrup et al., 2006; LaMarca et al., 2005; Low et al., 2001; Nickerson et al., 2001; Pulliam et al., 1991; Zhang, 2004). The application of this technique to human neuronal culture is particularly attractive in view of the cells' post-mitotic constraints in primary culture. We have shown here that 3-D culture evokes changes in SY cell morphology, proliferation, apoptosis resistance and differentiation states in a manner that narrows the phenotypic gap between those cells and their non-transformed counterparts. As studies involving human neuronal pathogenesis remain largely dependent on in vitro cell culture, this approach may easily be further exploited to create a more realistic environment in which to model nerve cell function and response.

\section{Supplementary Material}

Refer to Web version on PubMed Central for supplementary material.

\section{Acknowledgements}

This work was supported by grants NS048952 and RR00164 (MTP) from the National Institutes of Health. We thank Robin Rodriguez for technical assistance with our figure images.

\section{References}

Abbott A. Cell culture: biology's new dimension. Nature 2003;424:870-2. [PubMed: 12931155]

Anderson KD, Morin MA, Beckel-Mitchener A, Mobarak CD, Neve RL, Furneaux HM, Burry R, Perrone-Bizzozero NI. Overexpression of $\mathrm{HuD}$, but not of its truncated form $\mathrm{HuD}$ I+II, promotes GAP-43 gene expression and neurite outgrowth in PC12 cells in the absence of nerve growth factor. Journal of neurochemistry 2000;75:1103-14. [PubMed: 10936192]

Aranda-Abreu GE, Behar L, Chung S, Furneaux H, Ginzburg I. Embryonic lethal abnormal vision-like RNA-binding proteins regulate neurite outgrowth and tau expression in PC12 cells. J Neurosci 1999;19:6907-17. [PubMed: 10436048]

Attiah DG, Kopher RA, Desai TA. Characterization of PC12 cell proliferation and differentiationstimulated by ECM adhesion proteins and neurotrophic factors. Journal of materials science 2003;14:1005-9. [PubMed: 15348515]

Becker EB, Bonni A. Cell cycle regulation of neuronal apoptosis in development and disease. Progress in neurobiology 2004;72:1-25. [PubMed: 15019174]

Biedler JL, Helson L, Spengler BA. Morphology and growth, tumorigenicity, and cytogenetics of human neuroblastoma cells in continuous culture. Cancer research 1973;33:2643-52. [PubMed: 4748425]

Bolognani F, Perrone-Bizzozero NI. RNA-protein interactions and control of mRNA stability in neurons. J Neurosci Res 2008;86:481-9. [PubMed: 17853436]

Carterson AJ, Honer zu Bentrup K, Ott CM, Clarke MS, Pierson DL, Vanderburg CR, Buchanan KL, Nickerson CA, Schurr MJ. A549 lung epithelial cells grown as three-dimensional aggregates: alternative tissue culture model for Pseudomonas aeruginosa pathogenesis. Infection and immunity 2005;73:1129-40. [PubMed: 15664956]

Chagnovich D, Cohn SL. Binding of a 40-kDa protein to the N-myc 3'-untranslated region correlates with enhanced N-myc expression in human neuroblastoma. The Journal of biological chemistry 1996;271:33580-6. [PubMed: 8969225] 
Das PC, McElroy WK, Cooper RL. Differential modulation of catecholamines by chlorotriazine herbicides in pheochromocytoma (PC12) cells in vitro. Toxicol Sci 2000;56:324-31. [PubMed: 10910990]

Ding XL, Husseman J, Tomashevski A, Nochlin D, Jin LW, Vincent I. The cell cycle Cdc25A tyrosine phosphatase is activated in degenerating postmitotic neurons in Alzheimer's disease. The American journal of pathology 2000;157:1983-90. [PubMed: 11106571]

Ebelt H, Hufnagel N, Neuhaus P, Neuhaus H, Gajawada P, Simm A, Muller-Werdan U, Werdan K, Braun T. Divergent siblings: E2F2 and E2F4 but not E2F1 and E2F3 induce DNA synthesis in cardiomyocytes without activation of apoptosis. Circulation research 2005;96:509-17. [PubMed: 15718499]

Eisenstein M. Thinking Outside the Dish. Nature Methods 2006;3:1035-43.

Elyaman W, Terro F, Suen KC, Yardin C, Chang RC, Hugon J. BAD and Bcl-2 regulation are early events linking neuronal endoplasmic reticulum stress to mitochondria-mediated apoptosis. Brain research 2002;109:233-8. [PubMed: 12531534]

Encinas M, Iglesias M, Liu Y, Wang H, Muhaisen A, Cena V, Gallego C, Comella JX. Sequential treatment of SH-SY5Y cells with retinoic acid and brain-derived neurotrophic factor gives rise to fully differentiated, neurotrophic factor-dependent, human neuron-like cells. Journal of neurochemistry 2000;75:991-1003. [PubMed: 10936180]

Fallon KB, Havlioglu N, Hamilton LH, Cheng TP, Carroll SL. Constitutive activation of the neuregulin-1/ erbB signaling pathway promotes the proliferation of a human peripheral neuroepithelioma cell line. Journal of neuro-oncology 2004;66:273-84. [PubMed: 15015657]

Fan L, Iyer J, Zhu S, Frick KK, Wada RK, Eskenazi AE, Berg PE, Ikegaki N, Kennett RH, Frantz CN. Inhibition of $\mathrm{N}$-myc expression and induction of apoptosis by iron chelation in human neuroblastoma cells. Cancer research 2001;61:1073-9. [PubMed: 11221835]

Freshney, RI. Culture of Animal Cells; A Manual of Basic Technique. Wiley-Liss, Inc; New York: 2000.

Gao H, Ayyaswamy PS, Ducheyne P. Dynamics of a microcarrier particle in the simulated microgravity environment of a rotating-wall vessel. Microgravity science and technology 1997;10:154-65. [PubMed: 11543416]

Garcia-Gil M, Pesi R, Perna S, Allegrini S, Giannecchini M, Camici M, Tozzi MG. 5'-aminoimidazole-4carboxamide riboside induces apoptosis in human neuroblastoma cells. Neuroscience 2003;117:81120. [PubMed: 12654334]

Grandinetti KB, Spengler BA, Biedler JL, Ross RA. Loss of one HuD allele on chromosome \#1p selects for amplification of the N-myc proto-oncogene in human neuroblastoma cells. Oncogene 2006;25:706-12. [PubMed: 16278682]

Greene LA, Tischler AS. Establishment of a noradrenergic clonal line of rat adrenal pheochromocytoma cells which respond to nerve growth factor. Proceedings of the National Academy of Sciences of the United States of America 1976;73:2424-8. [PubMed: 1065897]

Guidi A, Dubini G, Tominetti F, Raimondi M. Mechanobiologic Research in a Microgravity. Environment Bioreactor 2002:1-9.

Hammerling U, Bjelfman C, Pahlman S. Different regulation of N- and c-myc expression during phorbol ester-induced maturation of human SH-SY5Y neuroblastoma cells. Oncogene 1987;2:73-7. [PubMed: 3325885]

Hammond TG, Hammond JM. Optimized suspension culture: the rotating-wall vessel. American journal of physiology 2001;281:F12-25. [PubMed: 11399642]

Hanada M, Krajewski S, Tanaka S, Cazals-Hatem D, Spengler BA, Ross RA, Biedler JL, Reed JC. Regulation of Bcl-2 oncoprotein levels with differentiation of human neuroblastoma cells. Cancer research 1993;53:4978-86. [PubMed: 8402688]

Hanahan D, Weinberg RA. The hallmarks of cancer. Cell 2000;100:57-70. [PubMed: 10647931]

Henshall DC, Araki T, Schindler CK, Lan JQ, Tiekoter KL, Taki W, Simon RP. Activation of Bcl-2associated death protein and counter-response of Akt within cell populations during seizure-induced neuronal death. J Neurosci 2002;22:8458-65. [PubMed: 12351720]

Herrup K, Neve R, Ackerman SL, Copani A. Divide and die: cell cycle events as triggers of nerve cell death. J Neurosci 2004;24:9232-9. [PubMed: 15496657] 
Ho R, Minturn JE, Hishiki T, Zhao H, Wang Q, Cnaan A, Maris J, Evans AE, Brodeur GM. Proliferation of human neuroblastomas mediated by the epidermal growth factor receptor. Cancer research 2005;65:9868-75. [PubMed: 16267010]

Honer zu Bentrup K, Ramamurthy R, Ott CM, Emami K, Nelman-Gonzalez M, Wilson JW, Richter EG, Goodwin TJ, Alexander JS, Pierson DL, Pellis N, Buchanan KL, Nickerson CA. Three-dimensional organotypic models of human colonic epithelium to study the early stages of enteric salmonellosis. Microbes and infection/Institut Pasteur 2006;8:1813-25. [PubMed: 16730210]

Jiang Y, Saavedra HI, Holloway MP, Leone G, Altura RA. Aberrant regulation of survivin by the RB/ E2F family of proteins. The Journal of biological chemistry 2004;279:40511-20. [PubMed: 15271987]

Joshi S, Guleria RS, Pan J, Dipette D, Singh US. Heterogeneity in retinoic acid signaling in neuroblastomas: Role of matrix metalloproteinases in retinoic acid-induced differentiation. Biochimica et biophysica acta 2007;1772:1093-102. [PubMed: 17611083]

Kang JH, Rychahou PG, Ishola TA, Qiao J, Evers BM, Chung DH. MYCN silencing induces differentiation and apoptosis in human neuroblastoma cells. Biochemical and biophysical research communications 2006;351:192-7. [PubMed: 17055458]

Kaushal DCWN. Analyzing and Visualizing Expression Data with Spotfire. Current Protocols in Bioinformatics. 2004

Kuiper RP, Schoenmakers EF, van Reijmersdal SV, Hehir-Kwa JY, van Kessel AG, van Leeuwen FN, Hoogerbrugge PM. High-resolution genomic profiling of childhood ALL reveals novel recurrent genetic lesions affecting pathways involved in lymphocyte differentiation and cell cycle progression. Leukemia 2007;21:1258-66. [PubMed: 17443227]

Kunz-Schughart LA, Groebe K, Mueller-Klieser W. Three-dimensional cell culture induces novel proliferative and metabolic alterations associated with oncogenic transformation. International journal of cancer 1996;66:578-86.

LaMarca HL, Ott CM, Honer Zu Bentrup K, Leblanc CL, Pierson DL, Nelson AB, Scandurro AB, Whitley GS, Nickerson CA, Morris CA. Three-dimensional growth of extravillous cytotrophoblasts promotes differentiation and invasion. Placenta 2005;26:709-20. [PubMed: 16226120]

Lazarova DL, Spengler BA, Biedler JL, Ross RA. HuD, a neuronal-specific RNA-binding protein, is a putative regulator of $\mathrm{N}$-myc pre-mRNA processing/stability in malignant human neuroblasts. Oncogene 1999;18:2703-10. [PubMed: 10348344]

Lelkes PI, Galvan DL, Hayman GT, Goodwin TJ, Chatman DY, Cherian S, Garcia RM, Unsworth BR. Simulated microgravity conditions enhance differentiation of cultured PC12 cells towards the neuroendocrine phenotype. In vitro cellular \& developmental biology 1998;34:316-25.

Li GN, Livi LL, Gourd CM, Deweerd ES, Hoffman-Kim D. Genomic and morphological changes of neuroblastoma cells in response to three-dimensional matrices. Tissue engineering 2007;13:103547. [PubMed: 17439391]

Li W, Sanki A, Karim RZ, Thompson JF, Soon Lee C, Zhuang L, McCarthy SW, Scolyer RA. The role of cell cycle regulatory proteins in the pathogenesis of melanoma. Pathology 2006;38:287-301. [PubMed: 16916716]

Lombet A, Zujovic V, Kandouz M, Billardon C, Carvajal-Gonzalez S, Gompel A, Rostene W. Resistance to induced apoptosis in the human neuroblastoma cell line SK-N-SH in relation to neuronal differentiation. Role of Bcl-2 protein family. European journal of biochemistry/FEBS 2001;268:1352-62. [PubMed: 11231287]

Low HP, Savarese TM, Schwartz WJ. Neural precursor cells form rudimentary tissue-like structures in a rotating-wall vessel bioreactor. In vitro cellular \& developmental biology 2001;37:141-7.

Martinez T, Pascual A. Identification of genes differentially expressed in SH-SY5Y neuroblastoma cells exposed to the prion peptide 106-126. The European journal of neuroscience 2007;26:51-9. [PubMed: 17596192]

Mobarak CD, Anderson KD, Morin M, Beckel-Mitchener A, Rogers SL, Furneaux H, King P, PerroneBizzozero NI. The RNA-binding protein HuD is required for GAP-43 mRNA stability, GAP-43 gene expression, and PKC-dependent neurite outgrowth in PC12 cells. Mol Biol Cell 2000;11:3191-203. [PubMed: 10982410] 
Murakami Y, Aizu-Yokota E, Sonoda Y, Ohta S, Kasahara T. Suppression of endoplasmic reticulum stress-induced caspase activation and cell death by the overexpression of Bcl-xL or Bcl-2. Journal of biochemistry 2007;141:401-10. [PubMed: 17301078]

Nechushtan A, Smith CL, Lamensdorf I, Yoon SH, Youle RJ. Bax and Bak coalesce into novel mitochondria-associated clusters during apoptosis. The Journal of cell biology 2001;153:1265-76. [PubMed: 11402069]

Nguyen HN, Wang C, Perry DC. Depletion of intracellular calcium stores is toxic to SH-SY5Y neuronal cells. Brain Res 2002;924:159-66. [PubMed: 11750901]

Nickerson CA, Goodwin TJ, Terlonge J, Ott CM, Buchanan KL, Uicker WC, Emami K, LeBlanc CL, Ramamurthy R, Clarke MS, Vanderburg CR, Hammond T, Pierson DL. Three-dimensional tissue assemblies: novel models for the study of Salmonella enterica serovar Typhimurium pathogenesis. Infection and immunity 2001;69:7106-20. [PubMed: 11598087]

Nickerson CA, Ott CM. A New Dimension in Modeling Infectious Disease. ASM News 2004:169-75.

Nickerson CA, Richter EG, Ott CM. Studying host-pathogen interactions in 3-D: organotypic models for infectious disease and drug development. J Neuroimmune Pharmacol 2007;2:26-31. [PubMed: 18040823]

O’Brien LE, Zegers MM, Mostov KE. Opinion: Building epithelial architecture: insights from threedimensional culture models. Nature reviews 2002;3:531-7.

Parisi T, Yuan TL, Faust AM, Caron AM, Bronson R, Lees JA. Selective requirements for E2f3 in the development and tumorigenicity of Rb-deficient chimeric tissues. Molecular and cellular biology 2007;27:2283-93. [PubMed: 17210634]

Park MT, Lee SJ. Cell cycle and cancer. Journal of biochemistry and molecular biology 2003;36:60-5. [PubMed: 12542976]

Pascale A, Amadio M, Scapagnini G, Lanni C, Racchi M, Provenzani A, Govoni S, Alkon DL, Quattrone A. Neuronal ELAV proteins enhance mRNA stability by a PKCalpha-dependent pathway. Proceedings of the National Academy of Sciences of the United States of America 2005;102:1206570. [PubMed: 16099831]

Pascale A, Gusev PA, Amadio M, Dottorini T, Govoni S, Alkon DL, Quattrone A. Increase of the RNAbinding protein $\mathrm{HuD}$ and posttranscriptional up-regulation of the GAP-43 gene during spatial memory. Proceedings of the National Academy of Sciences of the United States of America 2004;101:1217-22. [PubMed: 14745023]

Potter SM. Distributed processing in cultured neuronal networks. Progress in brain research 2001;130:49_ 62. [PubMed: 11480288]

Pregi N, Vittori D, Perez G, Leiros CP, Nesse A. Effect of erythropoietin on staurosporine-induced apoptosis and differentiation of SH-SY5Y neuroblastoma cells. Biochimica et biophysica acta 2006;1763:238-46. [PubMed: 16500719]

Pulliam L, Herndier BG, Tang NM, McGrath MS. Human immunodeficiency virus-infected macrophages produce soluble factors that cause histological and neurochemical alterations in cultured human brains. The Journal of clinical investigation 1991;87:503-12. [PubMed: 1671392]

Raguenez G, Desire L, Lantrua V, Courtois Y. BCL-2 is upregulated in human SH-SY5Y neuroblastoma cells differentiated by overexpression of fibroblast growth factor 1. Biochemical and biophysical research communications 1999;258:745-51. [PubMed: 10329457]

Ribas J, Boix J. Cell differentiation, caspase inhibition, and macromolecular synthesis blockage, but not BCL-2 or BCL-XL proteins, protect SH-SY5Y cells from apoptosis triggered by two CDK inhibitory drugs. Experimental cell research 2004;295:9-24. [PubMed: 15051486]

Rieff HI, Raetzman LT, Sapp DW, Yeh HH, Siegel RE, Corfas G. Neuregulin induces GABA(A) receptor subunit expression and neurite outgrowth in cerebellar granule cells. J Neurosci 1999;19:10757-66. [PubMed: 10594059]

Schmeichel KL, Bissell MJ. Modeling tissue-specific signaling and organ function in three dimensions. Journal of cell science 2003;116:2377-88. [PubMed: 12766184]

Scorrano, L.; Oakes, SA.; Opferman, JT.; Cheng, EH.; Sorcinelli, MD.; Pozzan, T.; Korsmeyer, SJ. Science. 300. New York, NY: 2003. BAX and BAK regulation of endoplasmic reticulum Ca2+: a control point for apoptosis; p. 135-9. 
Smith AG, Popov N, Imreh M, Axelson H, Henriksson M. Expression and DNA-binding activity of MYCN/Max and Mnt/Max during induced differentiation of human neuroblastoma cells. Journal of cellular biochemistry 2004;92:1282-95. [PubMed: 15258910]

Smith, CUM. Elements of Molecular Neurobiology. 2. John Wiley and Sons, Ltd; Chichester: 1996.

Straub TM, Honer zu Bentrup K, Orosz-Coghlan P, Dohnalkova A, Mayer BK, Bartholomew RA, Valdez CO, Bruckner-Lea CJ, Gerba CP, Abbaszadegan M, Nickerson CA. In vitro cell culture infectivity assay for human noroviruses. Emerging infectious diseases 2007;13:396-403. [PubMed: 17552092]

Tekautz TM, Zhu K, Grenet J, Kaushal D, Kidd VJ, Lahti JM. Evaluation of IFN-gamma effects on apoptosis and gene expression in neuroblastoma--preclinical studies. Biochimica et biophysica acta 2006;1763:1000-10. [PubMed: 16979248]

Tweddle DA, Malcolm AJ, Cole M, Pearson AD, Lunec J. p53 cellular localization and function in neuroblastoma: evidence for defective G(1) arrest despite WAF1 induction in MYCN-amplified cells. The American journal of pathology 2001;158:2067-77. [PubMed: 11395384]

Ulloth JE, Almaguel FG, Padilla A, Bu L, Liu JW, De Leon M. Characterization of methyl-betacyclodextrin toxicity in NGF-differentiated PC12 cell death. Neurotoxicology 2007;28:613-21. [PubMed: 17292476]

Unsworth BR, Lelkes PI. Growing tissues in microgravity. Nature medicine 1998;4:901-7.

van Golen CM, Soules ME, Grauman AR, Feldman EL. N-Myc overexpression leads to decreased beta1 integrin expression and increased apoptosis in human neuroblastoma cells. Oncogene 2003;22:266473. [PubMed: 12730680]

van Noesel MM, Pieters R, Voute PA, Versteeg R. The N-myc paradox: N-myc overexpression in neuroblastomas is associated with sensitivity as well as resistance to apoptosis. Cancer letters 2003;197:165-72. [PubMed: 12880977]

Vyas S, Juin P, Hancock D, Suzuki Y, Takahashi R, Triller A, Evan G. Differentiation-dependent sensitivity to apoptogenic factors in PC12 cells. The Journal of biological chemistry 2004;279:30983-93. [PubMed: 15133027]

Wang CX, Song JH, Song DK, Yong VW, Shuaib A, Hao C. Cyclin-dependent kinase-5 prevents neuronal apoptosis through ERK-mediated upregulation of Bcl-2. Cell death and differentiation 2006;13:1203-12. [PubMed: 16273078]

Xiong Y, Zhang H, Beach D. Subunit rearrangement of the cyclin-dependent kinases is associated with cellular transformation. Genes \& development 1993;7:1572-83. [PubMed: 8101826]

Zhang S. Beyond the Petri dish. Nature biotechnology 2004;22:151-2.

Zhou Q, Melkoumian ZK, Lucktong A, Moniwa M, Davie JR, Strobl JS. Rapid induction of histone hyperacetylation and cellular differentiation in human breast tumor cell lines following degradation of histone deacetylase-1. The Journal of biological chemistry 2000;275:35256-63. [PubMed: 10938272]

Zhu X, Raina AK, Smith MA. Cell cycle events in neurons. Proliferation or death? The American journal of pathology 1999;155:327-9. [PubMed: 10433924]

Zong WX, Li C, Hatzivassiliou G, Lindsten T, Yu QC, Yuan J, Thompson CB. Bax and Bak can localize to the endoplasmic reticulum to initiate apoptosis. The Journal of cell biology 2003;162:59-69. [PubMed: 12847083] 
A

B
$\%$ Viability

Doubling Time
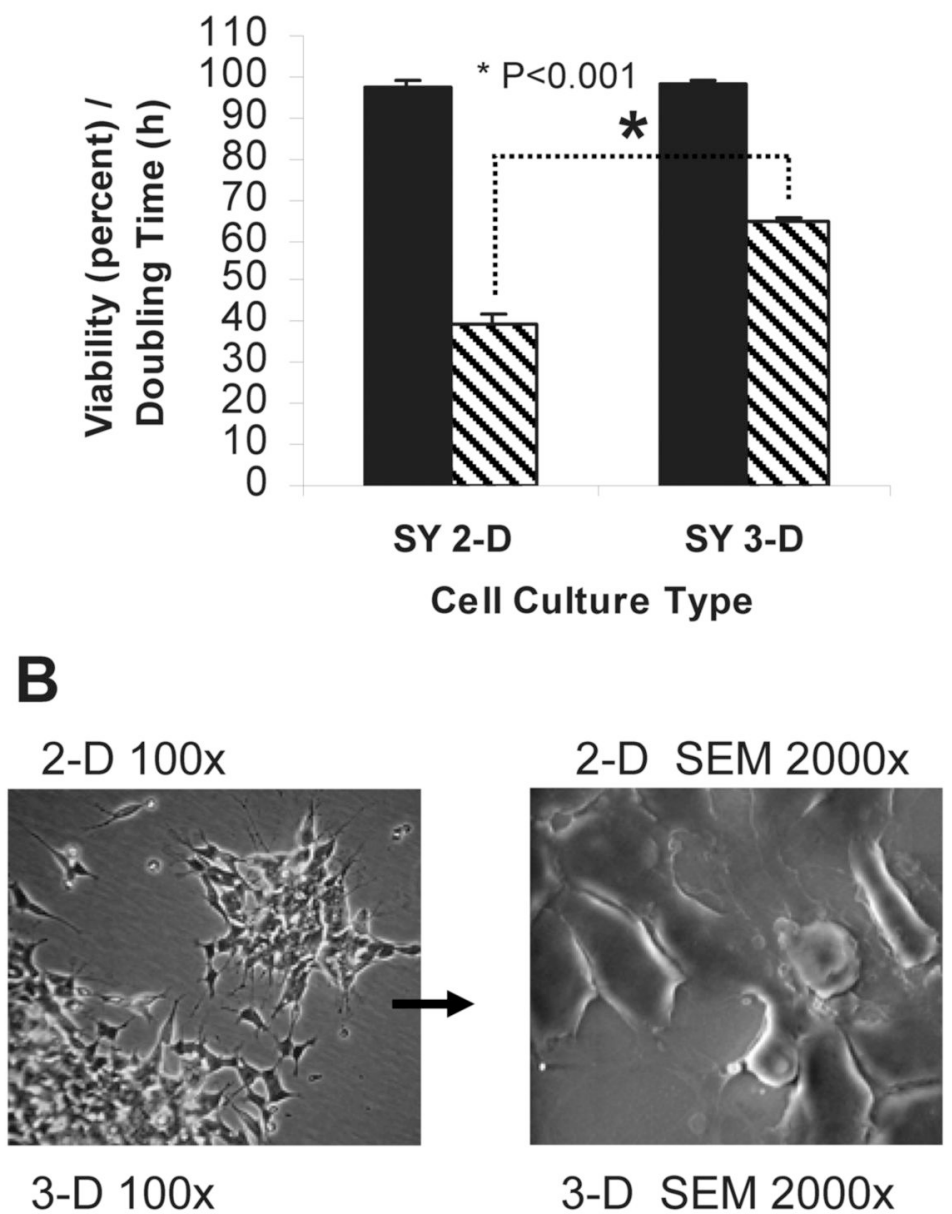

3-D SEM 2000x
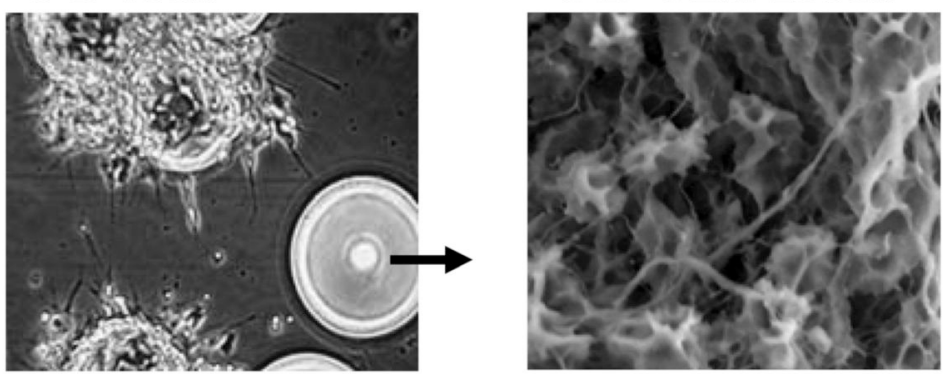

Figure 1. 3-D culture-induced changes in cell division rates and morphology

(A) After 3 weeks in RWV culture, the doubling rate of SY cells that were transferred back into 2-D culture for 5 days dropped from $1 \mathrm{x} / 40 \mathrm{~h}$ to $1 \mathrm{x} / 65$ hours, with no change in viability. Data are shown as the mean $(n=4) \pm S D . * P<0.001$ (B) SY cells grown in standard 2-D tissue culture flasks sediment to the bottom surface and have a flattened morphology. Culture in a RWV promotes 3-D assembly of the individual cells into large tissue-like aggregates. SEM: scanning electron micrograph. 
A
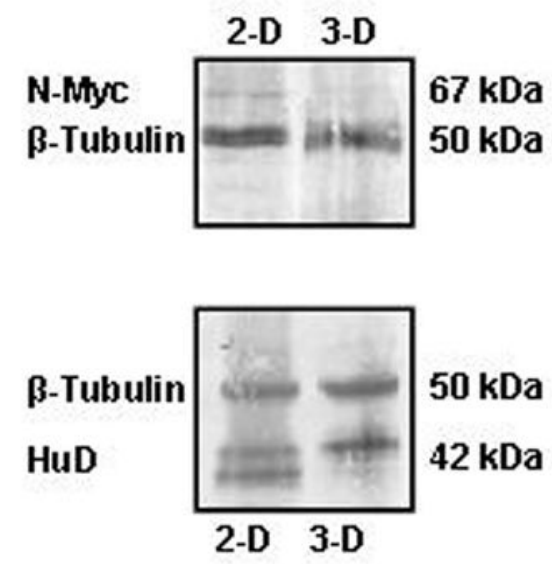

B

2-D
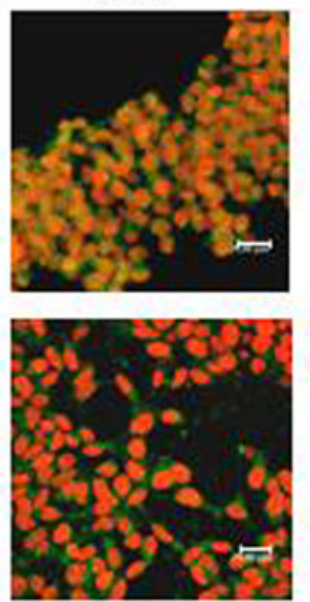

3-D
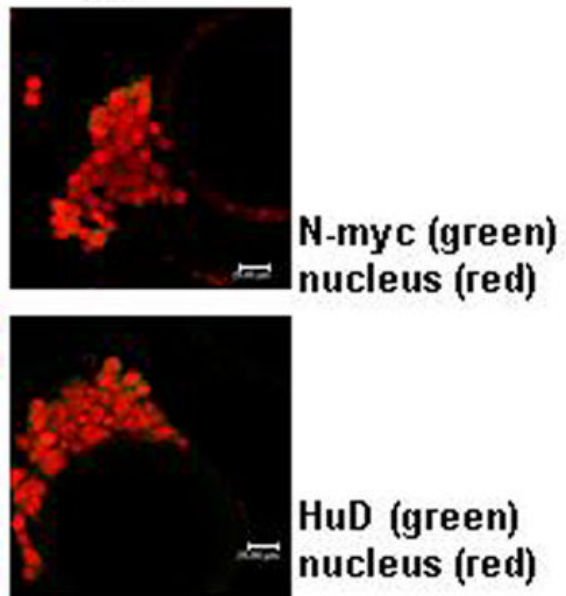

Figure 2. Decreased expression of $\mathrm{N}$-myc and $\mathrm{HuD}$ in 3-D versus 2-D-cultured SY cells (A) Western blot analysis reveals a decrease in the expression of $\mathrm{N}$-myc and HuD proteins in cells that were propagated for 4 weeks in 3-D culture that does not occur during growth in 2D. (B) Confocal images showing expression of the N-myc oncogene and the neuron-specific RNA-binding protein HuD. The 3-D culture was maintained for 4 weeks. The secondary antibody to N-myc and HuD is labeled with Alexa 488 (green). PI (red) was used as the nuclear stain. The scale bar on each image represents $20 \mu \mathrm{m}$. 
A (1)
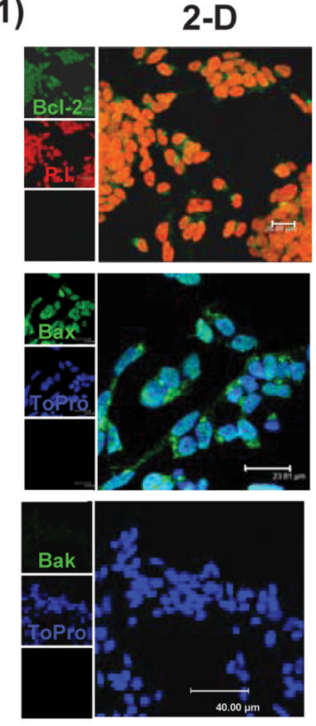

3-D
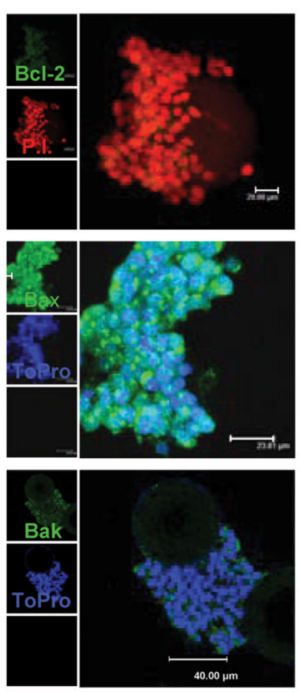

(2)

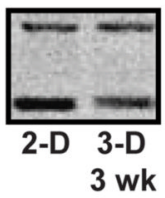

$\beta$-actin $42 \mathrm{kDa}$

$\mathrm{Bcl}-226 \mathrm{kDa}$

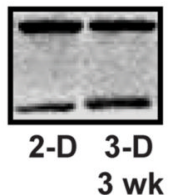

$\beta$-actin $42 \mathrm{kDa}$

Bax $29 \mathrm{kDa}$

$B$ (1)
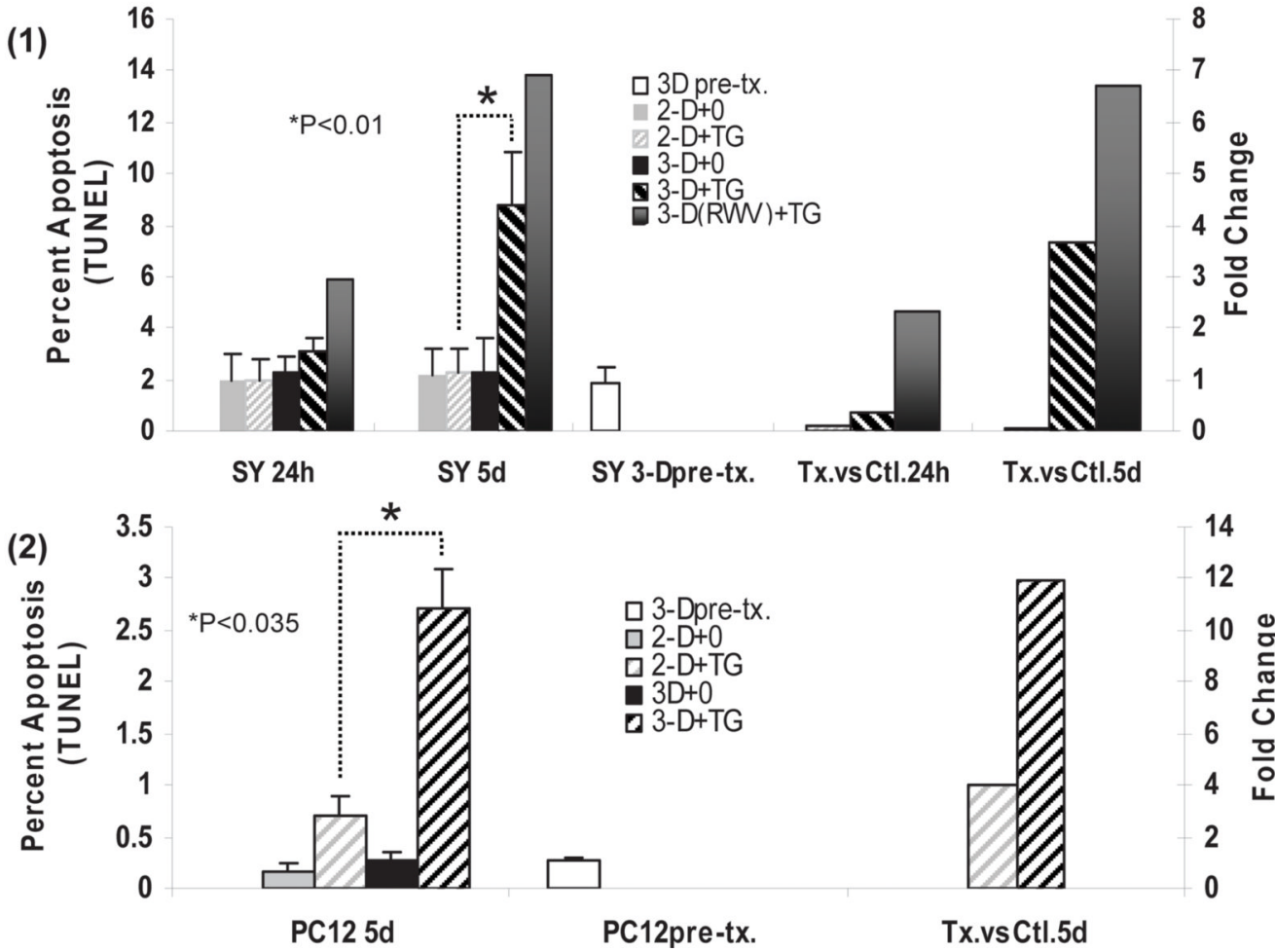

Figure 3. Resistance to apoptosis is diminished in 3-D-cultured SY cells

(A) 1-Confocal microscopy reveals diminished expression of the anti-apoptotic protein Bcl-2 in SY cells cultured for 3 weeks in a RWV. Pro-apoptotic Bax and Bak proteins are up-regulated in 3-D culture. The secondary antibody $(\mathrm{AB})$ to $\mathrm{Bcl}-2$, Bax and Bak is labeled with Alexa 488 (green). PI (red) or To-Pro (blue) was used to stain the nucleus. Scale bars on the images are: Bcl-2 $20 \mu \mathrm{m}$, Bax 23.81 $\mu \mathrm{m}$, Bak $40 \mu \mathrm{m}$. (A) 2- Western analysis of whole-cell lysates collected from the 2-D and 3-D cultures at 3 weeks confirms that $\mathrm{Bcl}-2$ expression is down-regulated in 3-D cells, and expression of Bax is up. (B)1- The percent of TUNEL-positive SY cells in 3-D culture increased 4 to 7-fold above those in 2-D when treated with TG (10 nM). (B) 2- TUNELpositive PC12 cells in 3-D increased 3-fold above those in 2-D. For (B) 1 and 2: 3-D pre-tx = 
3-D cells from RWV just before transfer to dish. 2-D+0 $=2-\mathrm{D}$ cells, unstimulated, $2-\mathrm{D}+\mathrm{TG}=$ 2-D cells stimulated with TG, $3-\mathrm{D}+0=3-\mathrm{D}$ cells, unstimulated, $3-\mathrm{D}+\mathrm{TG}=3-\mathrm{D}$ cells removed from RWV to dish, stimulated with TG, 3-D $(\mathrm{RWV})+\mathrm{TG}=3-\mathrm{D}$ cells treated with TG inside of the RWV. Data are shown as the mean $(\mathrm{n}=3) \pm \mathrm{SD}$. $* \mathrm{P}<0.01$ in $\mathrm{SY}$ (except for the 3-DRWV $+\mathrm{TG}$, where $\mathrm{n}=1),{ }^{*} \mathrm{P}<0.035$ in $\mathrm{PC} 12$. $\mathrm{L}$ axis: actual percent apoptosis $\mathrm{R}$ axis: arbitrary units of fold change representing the actual apoptosis. 
N-myc

2-D

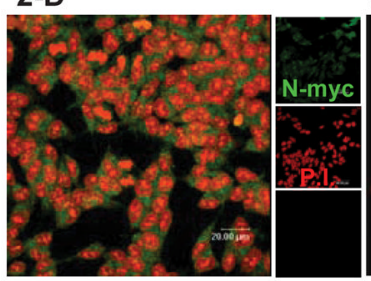

Bcl-2

2-D
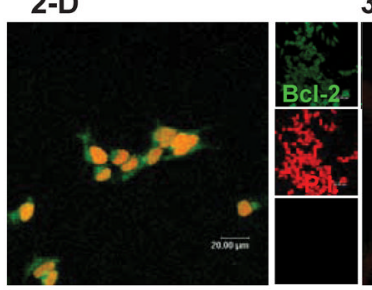

3-D

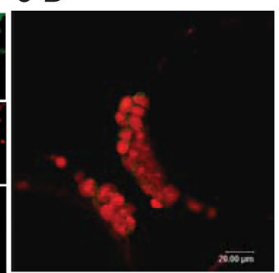

$5 \mathrm{~d}$

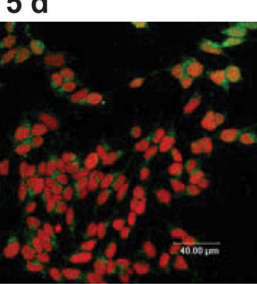

$10 d$

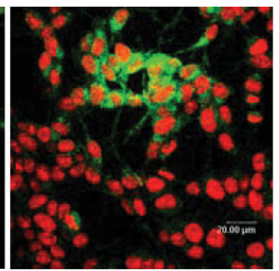

(3-D 2-D)

$5 \mathrm{~d}$

3-D
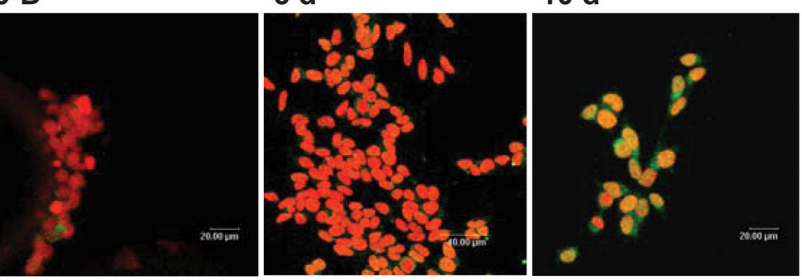

Figure 4. 3-D culture-driven changes in the phenotypic differentiation markers $\mathrm{N}$-myc and Bcl-2 are still apparent after $5 \mathrm{~d}$ of return to 2-D growth in tissue culture flasks

After 10 days of re-introduction to 2-D growth, marker expression in the 3-D cultured cells has returned to a level more analogous to those of the 2-D-cultured cell line. The secondary AB to N-myc and Bcl-2 is labeled with Alexa 488 (green). PI (red) was used as the nuclear stain. The scale bars on the 2-D and 3-D images represent $20 \mu \mathrm{m}$ except for 5 days, where the bar represents $40 \mu \mathrm{m}$. 
A

Functions and Diseases

Cancer

Cell Morphology

Cell Growth

and Proliferation

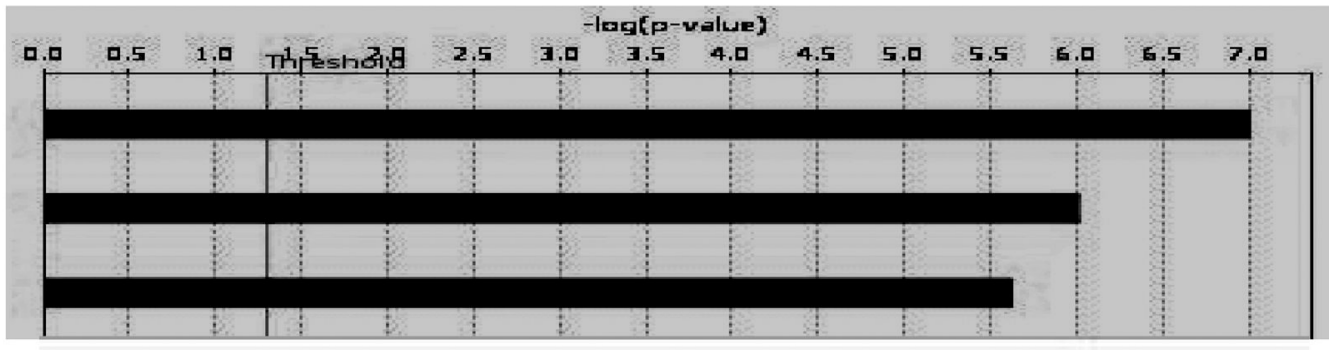

B

\section{Canonical Pathway Genes}

Cell Cycle: G1/S Checkpoint Regulation

Cell Cycle: G2/M DNA Damage Checkpoint Regulation,

P53 Signaling

Neuregulin Signaling

Hypoxia Signaling in the Cardiovascular System

IGF-1 Signaling

IL-2 Signaling

Insulin Receptor Signaling

FGF Signaling

PI3K/AKT Signaling

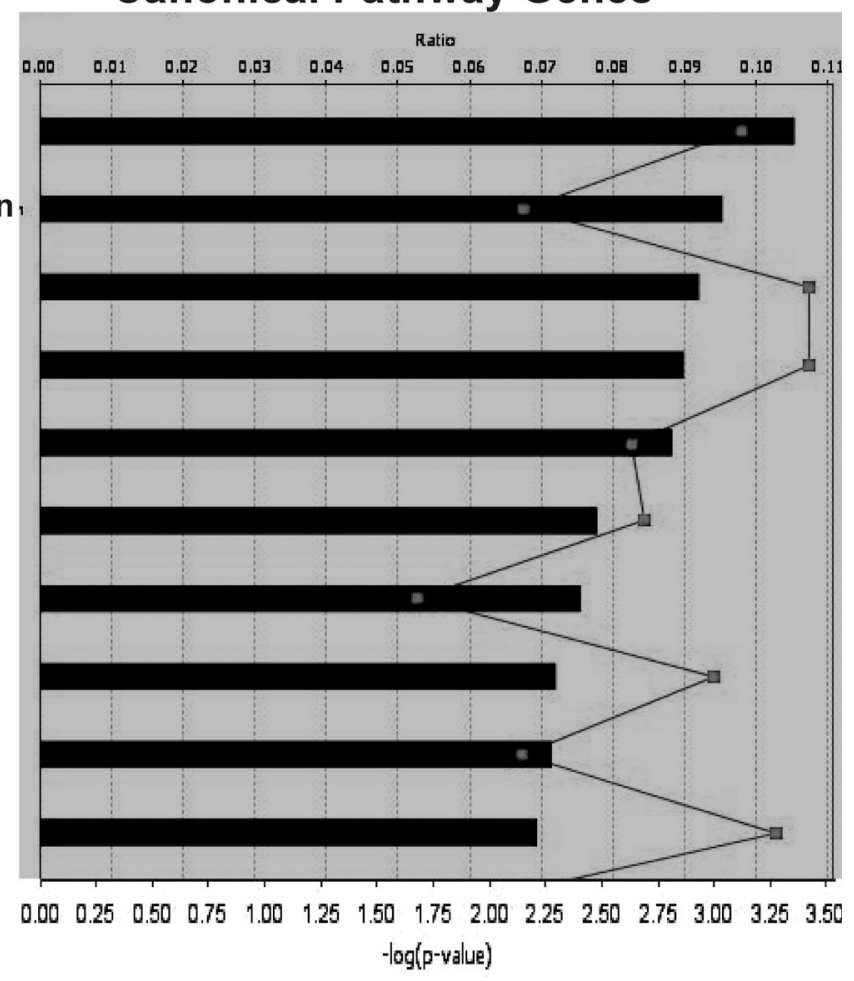




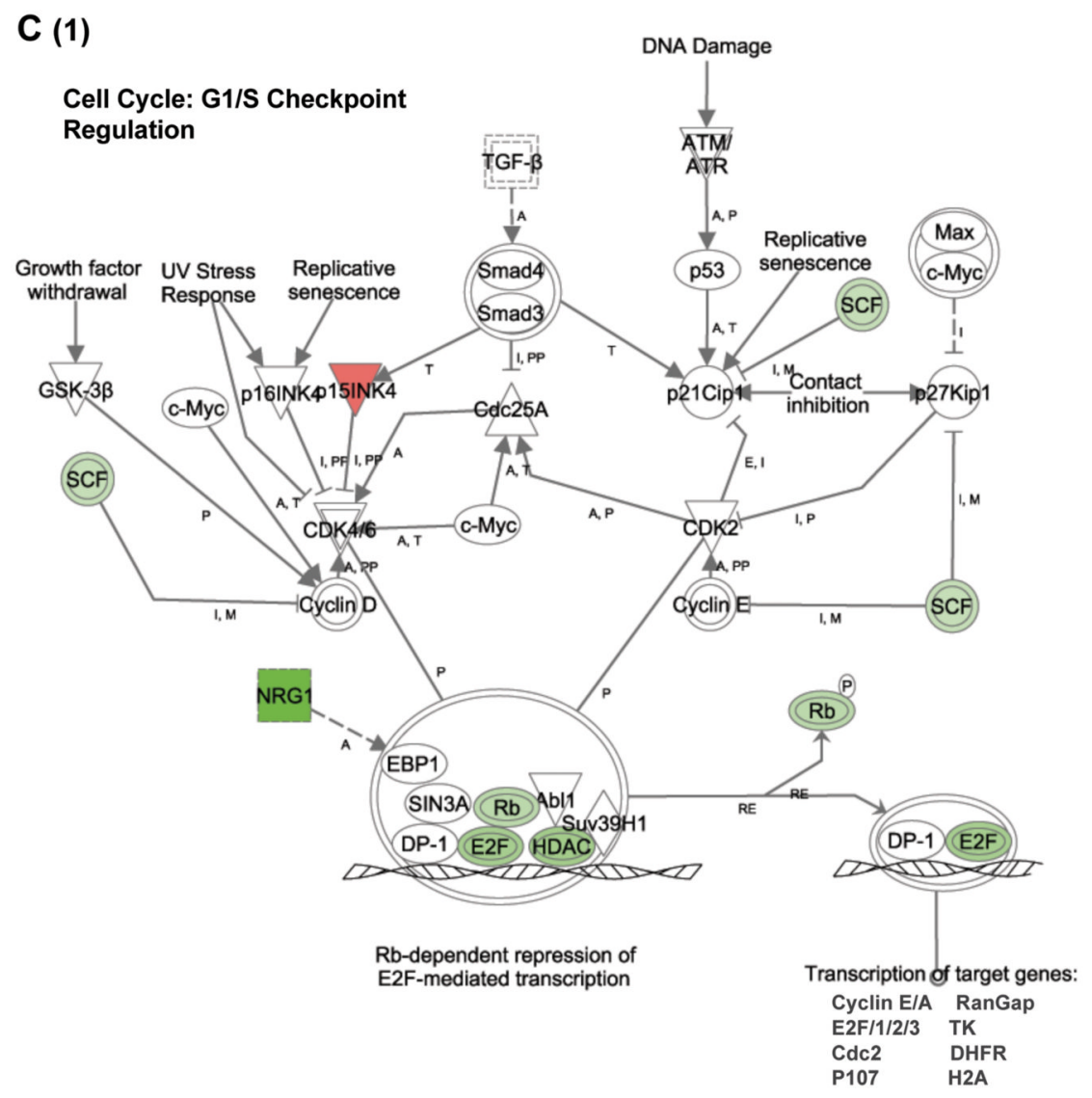

\begin{tabular}{|c|c|c|c|c|c|}
\hline $\begin{array}{l}\text { HUGO } \\
\text { Gene } \\
\text { Symbol }\end{array}$ & Description & $\begin{array}{l}\text { Log } \\
\text { Ratio }\end{array}$ & Location & Type & $\begin{array}{l}\text { Entrez } \\
\text { Gene } \\
\text { ID }(H)\end{array}$ \\
\hline CDKN2B & $\begin{array}{l}\text { cyclin-dependent kinase inhibitor 2B } \\
\text { (INK4, p15, inhibits CDK4) }\end{array}$ & +3.348 & Nucleus & transcription regulator & 1030 \\
\hline E2F3 & E2F transcription factor 3 & -2.15 & Nucleus & transcription regulator & 1871 \\
\hline HDAC2 & histone deacetylase 2 & -2.236 & Nucleus & transcription regulator & 3066 \\
\hline NRG1 & neuregulin 1 & -4.403 & Nucleus & extracellular space & 3084 \\
\hline RB1 & $\begin{array}{l}\text { retinoblastoma } 1 \\
\text { (including osteocarcinoma) }\end{array}$ & -1.574 & Nucleus & transcription regulator & 5925 \\
\hline SKP1A & $\begin{array}{l}\text { S-phase kinase-associated protein 1A } \\
\text { (p19A) }\end{array}$ & -1.325 & Nucleus & transcription regulator & 6500 \\
\hline
\end{tabular}

Molecules associated with cell cycle G1/S checkpoint regulation in SY 2-D and 3-D cells above $50 \%$ change.

Figure 5. Comparison of gene expression in 2-D and 3-D-cultured SY cells using microarray analysis

(A) Changes in gene expression due to cell culture conditions affect cellular disease-related pathways (top three of 63, shown in order of significance). Threshold = cutoff for $\mathrm{P}<0.05$. (B) Ten canonical pathways most affected in SY cells grown in 3-D rather than 2-D. Bar graph = ratio of gene expression in 3-D cultured cells as compared to those grown in 2-D. Line graph represents significance as $-\log (\mathrm{p}$-value $)$ with $\mathrm{P}<0.05$. (C) Gene expression pathway and results for G1/S cell cycle progression. Values were obtained using IPA software, version 5.0. Minimum fold change $\geq 1.5$. (D) (Table 2 ) Confirmation of array results using QRT-PCR. Reactions were run in triplicate with GAPDH gene expression being used as the reference. 
PCR efficiencies, average fold change and statistical analysis was performed using the REST@ software program. All genes in this pathway were represented on the chips. Red: increased gene expression. Green: decreased gene expression. mRNA for the QRT-PCR and array analysis was collected at passage 8 (2-D and 3-D cultures) with $n=2$ for each culture type. 
Table 1

Confirmation of array results using QRT-PCR.

\begin{tabular}{ccc}
\hline Gene & 3-D (fold change) & P-value \\
\hline${ }^{*}$ CDKN2B & +4.04 & 0.001 \\
E2F3 & +1.00 & 0.947 \\
${ }^{*}$ HDAC2 & -1.57 & 0.050 \\
& -2.39 & 0.001 \\
\hline
\end{tabular}

Reactions were run in triplicate with GAPDH gene expression being used as the reference. PCR efficiencies, average fold change and statistical analysis was performed using the REST () software program.

P $\leq 0.05$ 